\title{
<技術論文 $>$
}

\section{熱溶着（ヒートシール）の溶着面における 剥離エネルギーの計測と評価法の提案}

\author{
菱沼一夫* \\ 要 旨
}

プラスチックのフイルムやシートの接着には熱溶着が適用されているが, 加熱温度によって, 剥がれシー ルと破れシールが発現する。

現状ではこれらのヒートシール面の明確な強度評価法が提示されていない。本研究では剥離エネルギーに 基づく強度評価法を提案し，その有効性について確認した。

\section{1. 緒 言}

プラスチックの包装資材のほとんどの接着には熱溶着 (ヒートシール) が使われる。熱溶着（ヒートシール）に は熱可塑性の単一素材又は複数の素材にブロック共重合体 を用いて貼り合わせたプラスチックのフイルムやシートが 使用される。熱溶着（ヒートシール）は熱溶着層（ヒート シーラント）を溶融温度以上に加熱／圧着することによっ て成立する。ヒートシーラントの表層からの発熱体の直接 接触加熱や電磁波や超音波によるフイルム内部の界面の発 熱による加熱方法がある。

現行の代表的なヒートシール方法と特徵を Table 1 に 示した。最む多く使用されている一対の発熱ブロックで被 加熱体を挟み込んで加熱するヒートジョ一方式のメカニズ ムを Fig. 1 に示した。両面が同一温度の加熱の場合には, 加熱ブロックの圧着によって, 被加熱材は表面から温度が 上昇して接触界面の溶着層に伝熱加熱される。Fig. 1 には 圧着開始 $(t=0)$ から $(t=1),(t=2)$ の材料内部の温度 分布を図解したものを示している。両面加熱の場合は溶着 界面の温度応答は, 材料の初期温度の影響を少し受けて, 材料厚さと熱容量によって決定される。

片面加熱の場合は一方からの加熱流のみに依存するので 溶着界面の温度応答は材料の初期温度, 材料厚さ之熱容量, 更に受け台の温度によって決定される。繰り返しの加熱操

* 菱沼技術士事務所

川崎市幸区小倉 1232 于 $212-0054$

(原稿受付日: 平成 17 年 8 月 23 日)
作によって受け台の温度は変動するので加熱流に影響して, 片面加熱の溶着界面の温度制御は両面加熱より難しい。ヒー トシールは加熱温度によって溶着状態は大別して以下の 2 通りがある。

（1）ヒートシーラントの溶着面の界面のみで接着する剥 がれシール (Peel seal)

（2）ヒートシーラントが高温加熱により完全に溶融接着 して溶着面のエッジが破断する破れシール（Tear seal)

熱溶着（ヒートシール）操作によって発生する Peel seal と Tear seal の部位の説明と引張試験の剥がれと破れの状 態 ${ }^{2)}$ を Fig. 2 に示した。

2 つの溶着状態は加熱温度で变化するので, 加熱温度は ヒートシール完成と信頼性に強く関係している。

熱溶着のヒートシール強さは引張試験によって評価され てきている。従来は引張試験の最大值を以って接着（溶着） の状態の評価を行っている1,2)。

この評価法は破断点までの破断エネルギーの考え方に基 いている3)。熱溶着 (ヒートシール) では, 接着面が数 $\mathrm{mm}$ から 10 数 $\mathrm{mm}$ までの巾のヒートシール面 (Fin) を作っ ている。(Photo. 1 参照)

プラスチックのフィルムや薄手のシートでの場合には, 引き裂き応力は溶着面全体にかかるのではなく応力ライン 線上に作用する。奏際では, エッジで破断する破れシール (Tear seal) の加熱方法が “常態的” に適用されているの で,フィンの機能は接着に関しては利用されていない。

従来, 熱溶着 (ヒートシール) に関連する不具合が発生 すると，破断エネルギー理論をよりどころにして，包装材 
Table 1 Kind and Characteristics of Heat Seal Technology

\begin{tabular}{|c|c|c|c|c|c|}
\hline \multirow{2}{*}{ Method } & \multicolumn{2}{|c|}{ Heating Surface } & \multirow{2}{*}{ Principle of Heating } & \multirow{2}{*}{ Characteristics } & \multirow{2}{*}{ Use } \\
\hline & Double & Single & & & \\
\hline (1) Heat Bar & 0 & 0 & $\begin{array}{l}\text { Conduction from } \\
\text { Front Surface }\end{array}$ & $\begin{array}{l}\text { - Big Capacity of } \\
\text { Heating (Double) } \\
\text { - Influence of Cradle } \\
\text { Temperature (Single) }\end{array}$ & $\begin{array}{l}\text {-Lamination Film } \\
\text {-Single Layer Film }\end{array}$ \\
\hline (2) Impulse & $(O)$ & 0 & $\begin{array}{l}\text { Conduction from } \\
\text { Front Surface }\end{array}$ & $\begin{array}{l}\text {-Small Capacity of Heating } \\
\text { - Heat Seal Fin is Small } \\
\text {-Easy Use, Low Cost }\end{array}$ & $\begin{array}{l}\text {-Single Layer Film } \\
\text {-Lamination Film (Thin) }\end{array}$ \\
\hline (3) Hot Air & 0 & O & Blow of Hot Air & $\begin{array}{l}\text {-Direct Heating for } \\
\text { Melting Surface } \\
\text { - Influence is Small of Heat } \\
\text { Conductance of Base Materia }\end{array}$ & $\begin{array}{l}\text { - Paper Carton } \\
\text { - Tube }\end{array}$ \\
\hline (4) Ultra Sonic & & 0 & $\begin{array}{l}\text { Energy Loss } \\
\text { Spread Division }\end{array}$ & $\begin{array}{l}\text { - Influence is Small of } \\
\text { Heat Conductance of } \\
\text { Base Material } \\
\text { - Inappropriate Character for } \\
\text { Metal Material }\end{array}$ & -Single Layer Film (Heavy) \\
\hline (5) Induction & & 0 & $\begin{array}{l}\text { Joule Heat of } \\
\text { Conduction Material }\end{array}$ & $\begin{array}{l}\text { - Need of Metal Material } \\
\text { - Heating Only Circumference }\end{array}$ & $\begin{array}{l}\text {-Metal Multi-lyre Film } \\
\text {-Heating Only Circumference }\end{array}$ \\
\hline (6) Electric Field & 0 & (O) & $\begin{array}{l}\text { Flush of Electric } \\
\text { Loss }\end{array}$ & $\begin{array}{l}\text { - Influence is Large of } \\
\text { Water Content of } \\
\text { Base Material }\end{array}$ & -Paper multi Layer Sheet \\
\hline
\end{tabular}

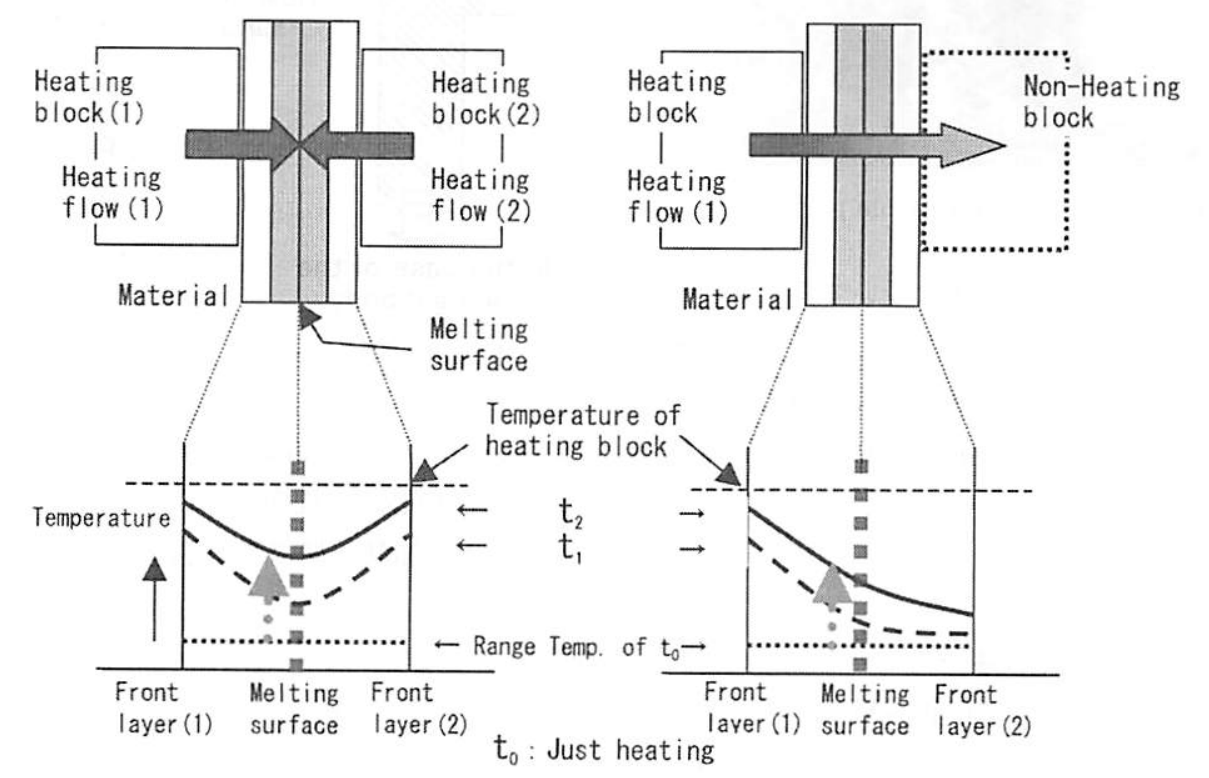

(a) Heating model of double heating (Same temperature)

(b) Heating model of single heating

Fig. 1 Heating flow model of heating block with heat sealing action

料の厚さや強度の強い材料の選択が行われている。

しかし, 厚さを増加させると, 材料の熱容量が増加する ので, 熱溶着 (ヒートシール) の加熱時間を変更前より長 く（運転速度を低下）するか, 加熱温度の高温化を必要と する。熱溶着（ヒートシール）の利用者の多くは, 生産性 を落としたくないので, 加熱温度の高温化を選択している。
加熱温度の高温化は以前より材料への熱ダメージを大きく するので材料の変更によって不具合の悪循環を起こしてし まっていることが多い。

本研究では, 熱溶着部位の熱ダメージの少ない Peel seal 領域の剥がれ現象における剥離エネルギーを利用する新規 な方法によって, プラスチック材料の適正な熱溶着（ヒー 


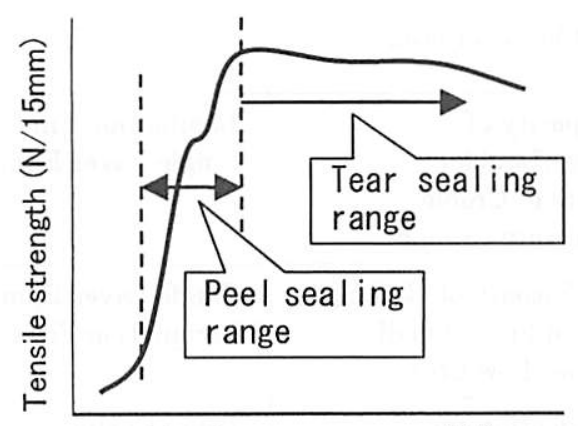

Heating temperature $\left({ }^{\circ} \mathrm{C}\right)$

(a)The genesis region place of peel seal and tear seal

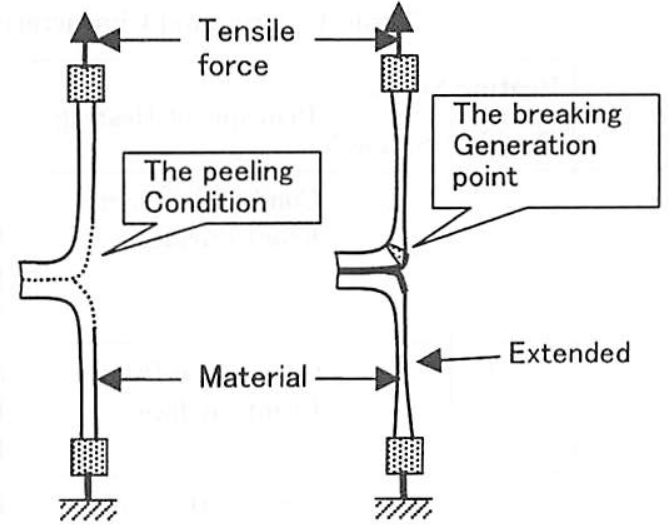

(b) The failure mode of peel sealing
(c)The failure mode of tear sealing

Fig. 2 The description of the failure modes ${ }^{2)}$ with the genesis region place of peel seal and tear seal

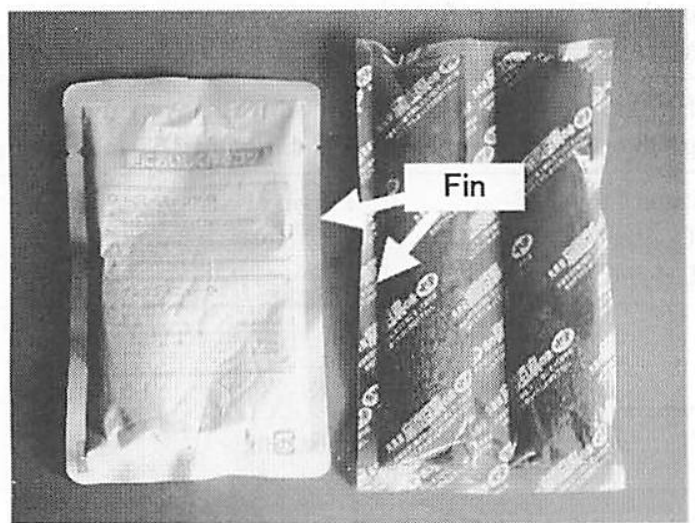

Photo. 1 Heat sealing Fin of the flexible packaging

トシール）性能を発揮させる改善方法について論ずる。

本研究で得られた結果から, 医薬, 医療包装品分野で要 求されている開封の際に接着面の微細な包装材料の破片の 発生が防御でき, III管中への異物の混入を避けることが期 待できる。

\section{2. 理 論}

\section{1 熱溶着の評価と破断エネルギー}

材料の強さを評価する方法として引張試験法が古くから 使われている。この方法は破断の起こった時の引張強さを 主な評価指標にしている。プラスチックの熱溶着（ヒート シール）の評価にもこの方法が準じて使われている1 2)。 引張試験法は剛性の大きい材料の破断面や接着面に引張応 力が均一にかかる場合の評価を主にしている。しかし，プ ラスチックシートのように柔らかく, 薄い材料の剛性は小 さい。従って, 熱溶着面全体に均一に引張応力はかからず, 溶着のエッジの《ヒートシール線》に応力が集中する4)。 引張応力によってヒートシール線には破れ又は, 剥れが生 じる。この様子を Fig. 3 に示した。従来の引張試験法で は計測値の最大值を以って溶着強さの評価をしているので,

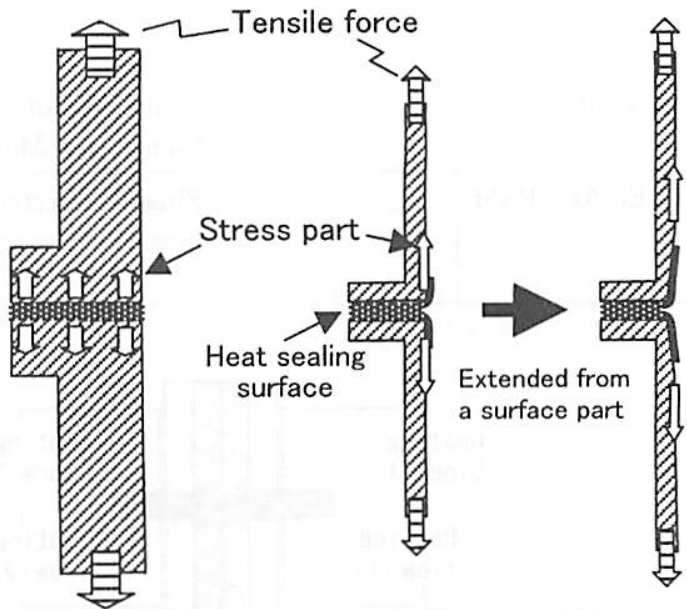

In the case of the usual rigid body
In the case of the heat sealing
Fig. 3 Stress which works to fusing surface

Peel seal より Tear seal の方が良好とされている。しか し包装製品の製造工程中や物流中で発生する衝撃や荷重で, Tear sealの加熱領域では包装袋のヒートシール線に破れ やピンホールが発生して, 食品包装・医薬品包装や高度の 酸素遮断を要求する精密機械部品の包装において, 不具合 の原因になっている。

\section{2 剥離エネルギー論の構築}

プラスチックは長さが数十 $\mu \mathrm{m}$ の系状の高分子が絡み 合った状態になっている。相対したヒートシーラントが加 熱によって軟化・半溶解した状態で加圧されると相対する ヒートシーラントは双方に数 $\mu \mathrm{m}$ 程度の“食い込み”を 起こす。この状態で泠却されると食い込み部分に摩擦接着 が起こり Peel seal の熱溶着が成立する。

他方, 融点 (Tm) 以上に加熱されて, 完全な溶融状態 で相対するヒートシーラントは“混合”状態となり, 冷却 されると系状の高分子は絡み合う。一部は酸化を起こすう 


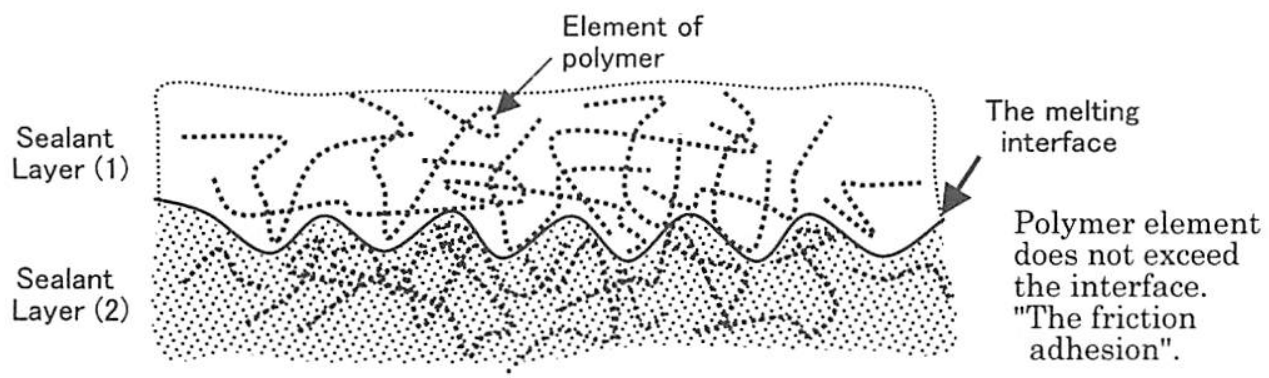

(a) The type of the condition of the peeling adhesion

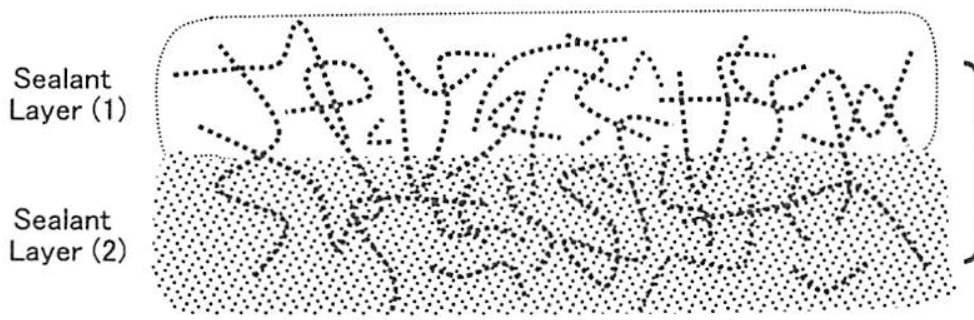

(b) The type of the condition of the tearing adhesion

The welding layer

The sealant is the mixing of the liquefaction.

Polymer element is combined in the entanglement.

Fig. 4 The schema of fusing condition of peel seal and tear seal

ジカル現象で高分子鎖の破断を起こすような Tear seal に 成る。2つの溶着状態の模式図を Fig. 4 に示した。

前者の熱接着状態は界面接着となり，ヒートシーラント の破断は起こらない。後者は双面のヒートシーラントは一 体化して接着界面は存在しなくなる。溶着面に応力が作用 すると各分子には不均一に応力がかかり, 系状の微小部位 に応力が集中して部分破断を起こし, 雪崩的にヒートシー ル線付近から破れると推定できる。

$15 \mathrm{~mm}$ 巾の引張強さ值の比較では

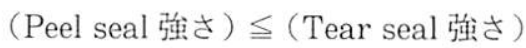

となる。小さい伸びや剥がれを伴う破断現象では, 単位巾 当たりの破断のエネルギー $[S t]$ は次式で表すことができ る。

$$
S t=\sum_{L=0}^{L t} k \cdot F_{(L)} \cdot \Delta l / w
$$

$S t:$ 破断エネルギー (J)

$F_{(L)}$ : 各引張距離点の引張強さ $(\mathrm{N})$

$\Delta l$ : エネルギー演算の設定単位距離 $(\mathrm{m})$

\section{（任意に設定）}

$L t:$ 破断の発生時の引張距離 $(\mathrm{m})$

$k$ : エネルギー演算距離の単位長さへ变換係数

$w:$ サプルヤ $(\mathrm{m})$

実際には，引張試験の応答の立ち上がりは鋭いのでこの 試験ではもっぱら強さ $\left[F_{(L)}\right]$ のみに着目している。破断 が起こらないPeel seal では引張強さは上昇後, 溶着巾の 剥がれの間は，ほぼ一定値となる。同一式を使い，積分範 囲を $\mathrm{L}=0$ から剥がれ巾の $\mathrm{Ln}$ までの積分を行う。この演 算を剥離エネルギー $[S p]$ と定義すると次式で表すことが できる。

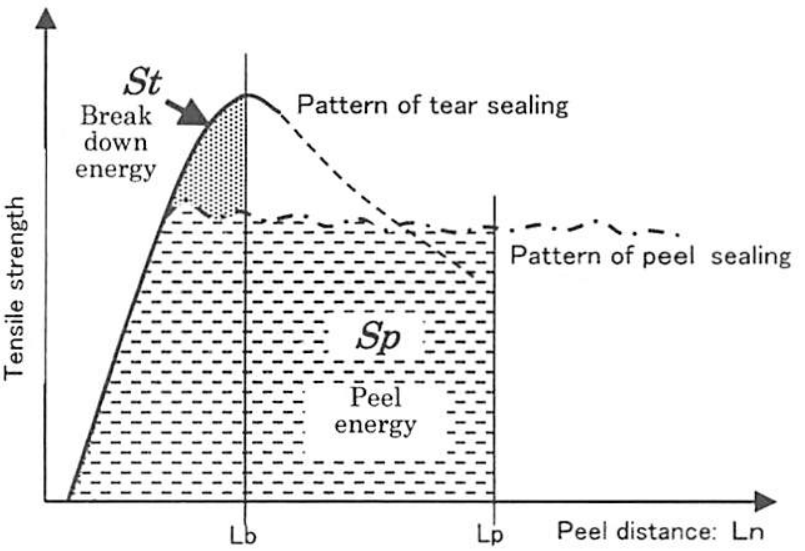

Fig. 5 Definition description of peel energy and break down energy

$S p=\sum_{L=0}^{L n} F_{(L)} \cdot \Delta l / w$

$[S p]$ : 剥離エネルギー $(J)$

$L n:$ 剥がれ巾 $(\mathrm{m})$

ここで定義した $[S t]$ と $[S p]$ の関係を Fig. 5 に示した。

\section{3 剥離エネルギーの活用の探求}

既に論じてきたように，プラスチックの熱溶着（ヒート シール）における破断強さは剥離強さより大きい。剥がれ が起こるように熱溶着して, 外力による発生する剥離/破 断エネルギーを剥離エネルギーに变換 (吸収/消費) すれ ば，破れの発生を抑制することができる。

すなわち “緩衝”機能で破断エネルギーを連続的に吸収 し, 破れ /ピンホールの発生を防御することができる。加 熱温度に依存する剥がれシール強さと剥がれ距離（ヒート シールFin 巾) の組み合わせで $(S p \geqq S t)$ が見出せれば, 
熱溶着（ヒートシール）の新規な信頼性向上と技法の開発 が可能になる。

\section{3. 実 験}

本実験では, 市販商品に使われているアルミラミネーショ ンの包装材料を使用した。

材料の構成は PET $(12 \mu \mathrm{m}) / \mathrm{PE}(15 \mu \mathrm{m}) / \mathrm{AL}(7 \mu \mathrm{m}) /$ $\mathrm{PE}(15 \mu \mathrm{m})$ である。各素材間の接着にはブロック共重合 の接着剂が使用されている。

\section{1 引張試験片の作成}

溶着面温度を直接加熱管理する溶着面温度測定法を適用 して ${ }^{5)}$ Peel seal 帯から Tear seal 帯の熱溶着サンプルを2 $\sim 10^{\circ} \mathrm{C}$ 間隔で加熱作成した。

\section{2 引張試験の方法}

各溶着面温度で加熱したサンプルを巾 $15 \mathrm{~mm}$, 引張試験 機にかける初期間隔が $30 \mathrm{~mm}$ になるように切断し，JIS 法 ${ }^{1)}$ に準じた引張試験を行う。引張試験機の引張距離と 引張強さの全データ（引張パターン）を $\mathrm{A} / \mathrm{D}$ 変換して パソコンに取り込む。引張試験の方法の構成図を Fig. 8 に示した。

\section{3 引張試験データの積分範囲と演算方法}

引張試験データの引張距離と引張強さ值をデジタル変換 して，全データをパソコンに“EXCEL”ファイルとして 取り込む。

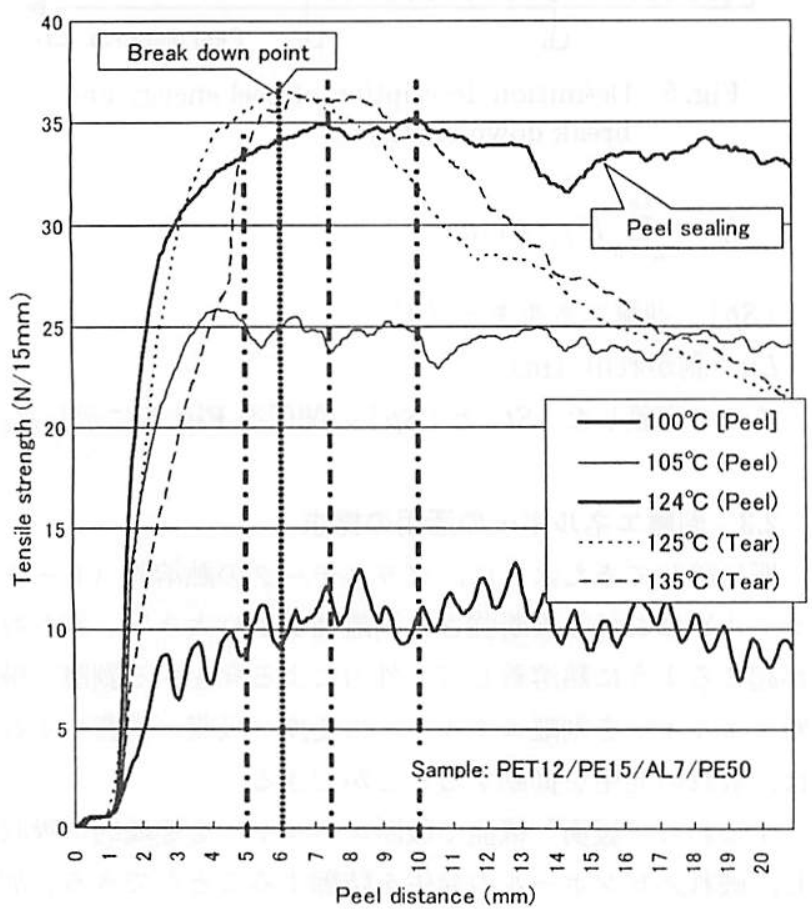

Fig. 6 Tension pattern example of the peel and tear sealing
(引張距離) $\times 1 / 2$ が剥離長さとなるので, 全引張距離 採取デー夕に $1 / 2$ を乗じた上で，長さを（m）に置換す る。全剥離長さは $10 \mathrm{~mm}$ 程度なので剥離距離の最小単位 は 0.1 0.2mm となるようデジタル変換し, 破断エネルギー と剥離エネルギーの近似積分の精度を確保するように考慮 した。引張值は $(\mathrm{N})$ に変換した。

剥がれのデジタル変換距離を $0.1 \mathrm{~mm}$ とすると,

$L n$ 点の仕事量は $\left(F_{(L n)} \times 0.1 / 1000\right)$

となる。

この場合には $k=1 / 1000$ となる。

加熱温度毎の “EXCEL”ファイルのデータの剥離開始 点から破れの発生点（降伏点）又は所定の剥がれ距離（例 えば； $5,7.5,10 \mathrm{~mm}$ ）までの全引張データの（総計） $\times$ （演算巾）の仕事量；剥離エネルギーを計算した。

\section{4. 実験結果及び考察}

\section{1 引張試験パターン}

実験の引張試験パターンは加熱温度毎に得られる。代表 例として, Peel seal ; 100, $105,124^{\circ} \mathrm{C}$ C Tear seal ; 125 , $135^{\circ} \mathrm{C}$ の張試験パターンを Fig. 6 に示した。

Peel seal ゾーンの加熱サンプルでは，ヒートシール強 さは立ち上がり後, 剥がれ範囲で加熱温度に応じたほぼ一 定の強さを維持している。他方 Tear seal は破れの発生と 共にヒートシール強さは下降している。引張試験パターン の立ち上がりが垂直にならないのは, 加熱線（ヒートシー ル線）は直線であるが非加熱面も加熱ブロックの輻射熱と 被加熱体からの伝熱で弱い溶着が発生しているためである。 Fig. 6 には㭘証した剥がれ距離の積分範囲（剥離エネルギー の計測範囲） $5,7.5,10 \mathrm{~mm}$ と破断点の縦線を付記した。 この縦線と引張試験パターンの交点までが剥離エネルギー の演算範冊となる。

\section{2 破断エネルギー, 剥離エネルギーの測定結果}

全ての加熱温度の引張試験パターンの剥離エネルギーと 破断エネルギーの演算処理結果を縦軸に仕事量 ( $\mathrm{J} / 15 \mathrm{~mm})$, 横軸を加熱温度（溶着面温度）ベースで集計した結果を Fig. 7 に示した。併せて従来の評価法である JIS 法 ${ }^{1)}$ のヒートシール強さを参考に付記した。

\section{3 剥離エネルギーの機能の考察}

Fig. 7 の結果から破断／剥離エネルギー解析から本実験 の包装材料では $125^{\circ} \mathrm{C}$ 付近に Peel seal と Tear seal の境 界温度があることが分かる。剥がれ巾が $5 \mathrm{~mm}$ の場合では， 剥離エネルギーは何れの温度帯でも破断エネルギーより小 さいので，ヒートシールフィンを利用した熱溶着の性能改 善には不適である。フィン幅が $5 \mathrm{~mm}$ 以下のヶースはイン 


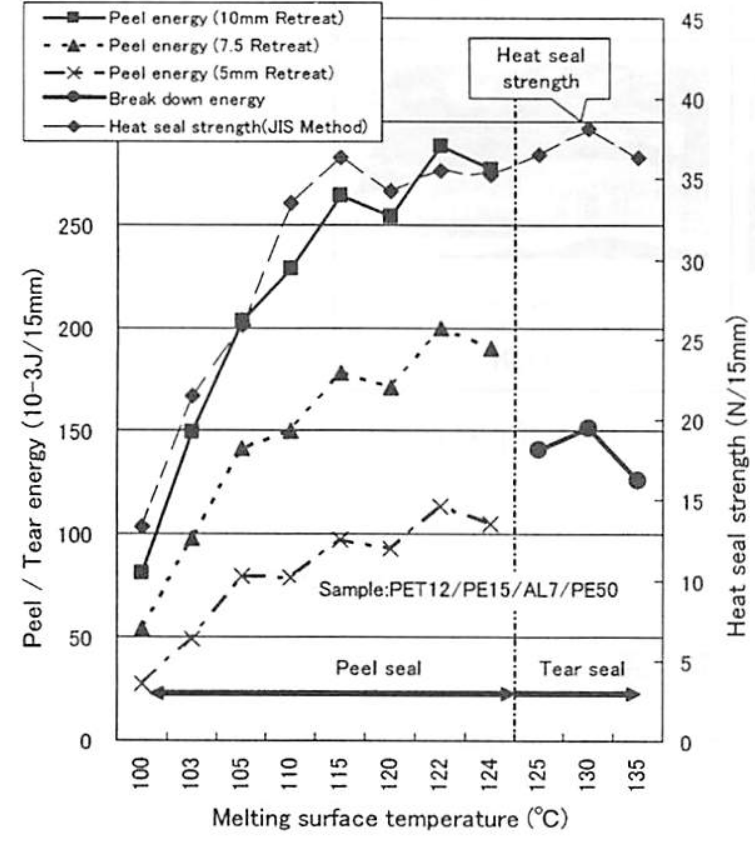

Fig. 7 The enforcement example of the peel energy method

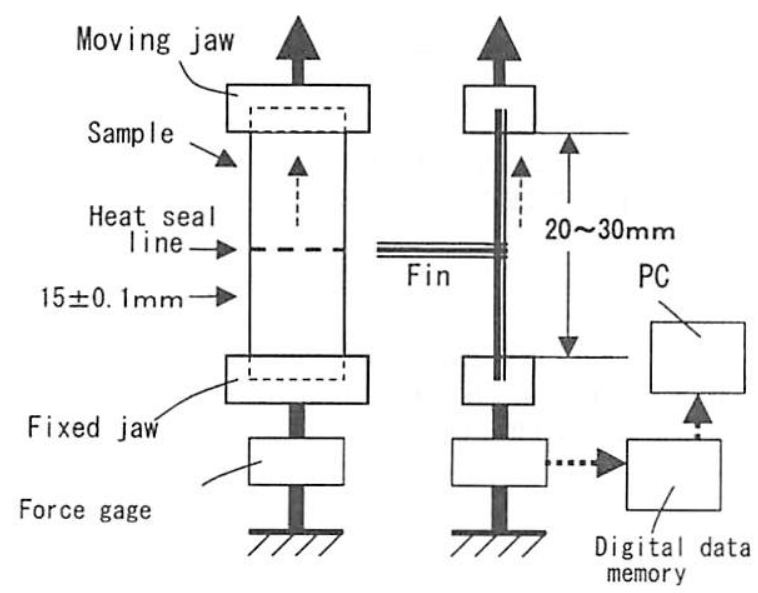

Fig. 8 The tensile test method for the peel and tear energy measurement

パルスシールのような細線状のヒートシール方式の採用の 場合に該当する。

剥がれ巾が $7.5 \mathrm{~mm}$ 以上になると，105〜 $124^{\circ} \mathrm{C}$ の広い温 度带で Peel sealの剥離エネルギーが Tear seal の破断エ ネルギーより大きくなり, 剥離エネルギー論の有用性を見 出すことができる。従来の JIS 法のヒートシール強さの 評価法ではヒートシール強さの立ち上がり後の熱溶着の状 態が識別できないので剥離エネルギーでの議論が困難であ ることが分かった。

従来のヒートシールの管理法では, 熱溶着は大きなヒー トシール強さの達成が至上命題であったが, 剥離エネルギー 論の適用で適正なヒートシール強さ制御の議論ができるよ うになった。

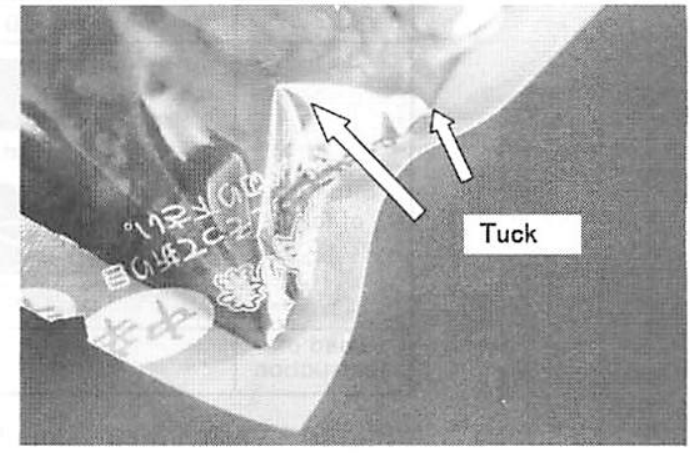

Photo. 2 The "tuck" seen to commercial goods

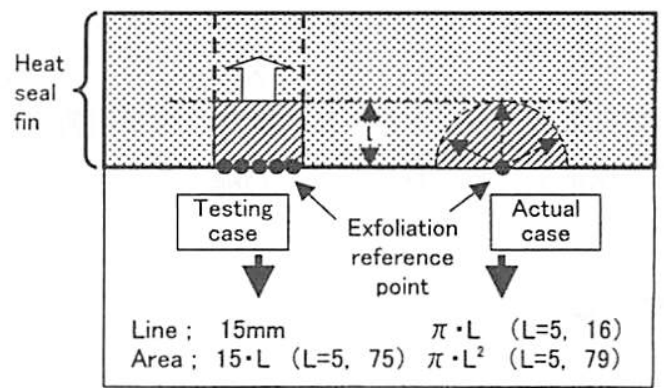

Fig. 9 Increase of the stress line by advance of exfoliation

\section{4 剥離エネルギー論の実際への適用効果の考察}

プラスチックを利用した包装袋（パウチ）はシート状の 材料を熱溶着によって袋状にしている。平面状の袋に製品 を充填して立体状にするので，パウチには原理的に必 ず“タック”が発生する。(Photo. 2 参照) 破袋やピンホー ルの発生は“タック”の頂点とヒートシール線の交点が起 点になって発生する。実際には, 奏験室の引張試験のよう に $15 \mathrm{~mm}$ 巾のヒートシール線に応力が均一にかかること

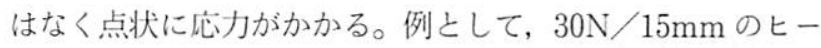
トシール強さを持つ材料の場合で，応力点の大きさを $1 \mathrm{~mm} \phi$ とすると $30 \mathrm{~N} / 15 \mathrm{~mm}=2 \mathrm{~N} / \mathrm{mm}^{*}$ となり, わずか な応力でもピンホールや剥がれが起こることになる。

実際はFig. 9 に示したように円弧状の剥がれが発生す る。剥がれゆをLとすれば，剥がれラインは（ なる。又, 剥がれ面積は $\left(\pi \cdot \mathrm{L}^{2}\right)$ になる。 $15 \mathrm{~mm}$ 巾の試 験結果で比較すると, L が $5 \mathrm{~mm}$ より大きくなると実験結 果に余裕が出てくる。別の解釈として, ヒートシールのフィ ン巾が $5 \mathrm{~mm}$ 以上にとれば Peel seal の適用で受圧応力線 の長さが剥れ巾の $\pi$ 倍になる。外力が一定ならば受圧応力 線が拡大するので, 単位長さ当たりの受圧応力は減少する ので, 剥がれ強さとバランスして剥離の進行を自己制御す る特長を利用できる。

\section{5 剥離エネルギー論の適用効果の確認}

実験に使用した同一の材料で $10 \times 10 \mathrm{~cm}$ サイズの 4 方 (辺) シールの袋を作成し, これに水を充填して, JIS 法 ${ }^{1)}$ 


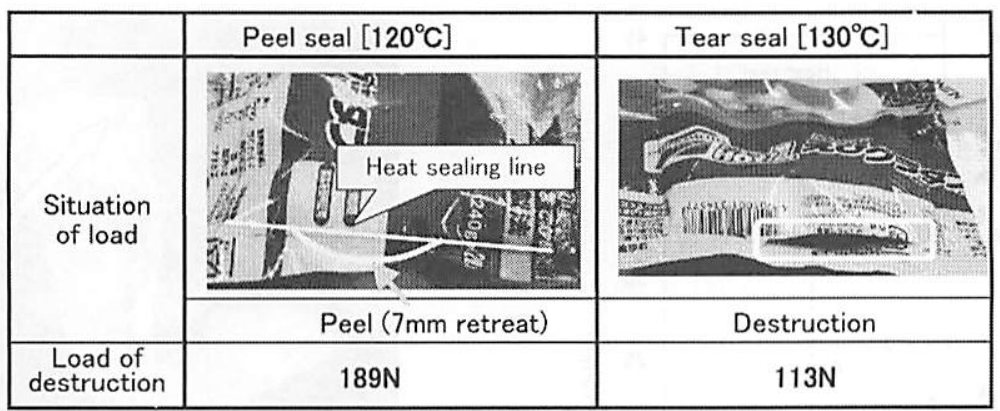

Fig. 10 Verification example of the application effect of peel energy

で荷重試験を行った。結果をFig. 10 に示した。

$130^{\circ} \mathrm{C}$ で熱溶着した Tear seal 袋では $113 \mathrm{~N}$ の荷重で破 袋した。他方, $120^{\circ} \mathrm{C}$ の Peel seal 袋では $189 \mathrm{~N}$ の荷重で, 剥がれ巾は最大 $7 \mathrm{~mm}$ であった。剥がれ線は円弧状であっ た。この検証から熱溶着における剥離エネルギー論の破袋 防御の有効性が確認できた ${ }^{6)}$ 。

\section{5. 結 論}

（1）剥離エネルギー論の実用的な有用性が確認できた。

（2）熱溶着（ヒートシール）における Peel seal 溶着の有 用性の検証できた。

（3）従来の評価法では包装材料の適正溶着の評価が困難 であることが分かった。

(4) 本研究の展開で破れ破片の発生しにくいP Peel seal の 積極的な適用が可能になる。

（5）ヒートシールのフィンウの適正設計ができるように なる。

（6）Peel sealの適用で高信頼な熱溶着（ヒートシール）
が可能となり, ヒートシーラントの厚さの増加が不 要になるので, 包装材料の廉価化が図れる。

\section{6. 謝 辞}

本研究の実験に協力戴いた味の素冷凍食品株式会社の角 田 光弘氏, プラスチックの溶融特性についてご指導を戴 いた小山コンサルティング事務所所長小山 武夫氏，研究 のご指導を戴いた東京大学大学院農学生命科学研究室小野 拡邦教授に紙面より感謝いたします。

\section{引 用 文 献}

1) JIS : Z 0238 (1998)

2) ASTM Designation: F88-00 (2000)

3）（社）日本包装技術協会，「包装技術便覧」，p. 981，p. 1394 (1995)

4）菱沼 一夫, 第 13 回日本包装学会年次大会要旨集, p. 92-, (2004)

5）菱沼 一夫，「日本包装学会誌」，14(2) 119 (2005)

6) U.S. Patent No. US 6,952,959 B2, Method of Designing a Heat Seal Width, October 11, 2005

\title{
$<$ Technical Report $>$
}

\section{The Proposal of the Evaluation and Measurement Method of Peeling Energy of the Heat Sealing on the Basis of Melting Surface}

\author{
Kazuo HISHINUMA* \\ *HISHINUMA CONSULTING ENGINEER OFFICE \\ 1232 Ogura Saiwai-ward Kawasaki-city Japan 212-0054 \\ (Accepted for publication : December 26, 2005)
}

\begin{abstract}
It is used by the heat sealing for the adhesion of plastic film and sheet.

Peeling seal and breaking seal manifest the adhesion condition by the heating temperature.

In present state, clear strength evaluation method of these heats sealing plane has not been presented.

In this study, strength evaluation method based on peeling energy was proposed, and the effectiveness was confirmed.
\end{abstract}

